\begin{tabular}{|l|l|l||}
\hline \multicolumn{2}{|c|}{ PublisherInfo } \\
\hline \hline PublisherName & $:$ & BioMed Central \\
\hline \hline PublisherLocation & $:$ & London \\
\hline \hline PublisherImprintName & $:$ & BioMed Central \\
\hline \hline
\end{tabular}

\title{
A tunicate bends the rules
}

\begin{tabular}{|l|c|l||}
\hline \multicolumn{2}{|c|}{ ArticleInfo } \\
\hline \hline ArticleID & $:$ & 4997 \\
\hline \hline ArticleDOI & $:$ & $10.1186 /$ gb-spotlight-20040902-01 \\
\hline \hline ArticleCitationID & $:$ & spotlight-20040902-01 \\
\hline \hline ArticleSequenceNumber & $:$ & 60 \\
\hline \hline ArticleCategory & $:$ & Research news \\
\hline ArticleFirstPage & $:$ & 1 \\
\hline \hline ArticleLastPage & $:$ & 3 \\
\hline \hline & & RegistrationDate : 2004-9-2 \\
\hline ArticleHistory & $:$ & OnlineDate \\
\hline \hline ArticleCopyright & $:$ & BioMed Central Ltd2004-9-2 \\
\hline \hline ArticleGrants & $:$ & \\
\hline \hline ArticleContext & $:$ & 130595511 \\
\hline \hline
\end{tabular}


Hox gene clusters are not necessary to build a chordate, a paper published in the September 2 issue of Nature shows. The finding raises questions about established beliefs on the subject of body plan development.

"If you open any textbook, you'll read that the Hox cluster is conserved in all bilaterian animals," Daniel Chourrout at the University of Bergen, Norway, told us. But his study of the tunicate Oikopleura dioica revealed its Hox genes to be distributed in nine locations around the genome.

Hox gene clusters specify the body plan of most multicellular animals, suggesting that they date back to the common ancestor of worms, arthropods and vertebrates. They are among the most highly conserved of genetic sequences, and display a collinear pattern of expression, whereby their sequence on a chromosome reflects where they are expressed along an animal's anteroposterior axis.

Chourrout said that a degree of Hox fragmentation has occurred in some insects and in the nematode Caenorhabditis elegans, but has not been found in any vertebrate studied to date. Tunicates are nonvertebrate members of the chordate phylum, whose affinity with vertebrates is evident in their tadpolelike larval stage.

Another tunicate, the sea-squirt Ciona intestinalis, also exhibits partial Hox cluster fragmentation, noted Chourrout, but this is far more pronounced in Oikopleura. Eight of Oikopleura's nine Hox genes were found to be more than 250 kilobases from their nearest Hox neighbor on either side. This extent of fragmentation is matched only in C. elegans, said Chourrout.

Nipam Patel, Howard Hughes investigator at the University of California, Berkeley, was also impressed by the scale of Hox fragmentation. Soon, he said, "we'll have the whole genome sequenced, and for all we know, they'll be on different chromosomes."

So, what is it about Oikopleura and C. elegans that allows them to relax the clustering rule? Or, as Patel asks in an accompanying News and Views article, what is the selective force that keeps the cluster intact in other animals?

Oikopleura reinforces the idea that, in most animals, Hox clusters are collinear not only in space on the chromosome, but also in time, Patel suggested. So, anterior genes at one end of the cluster are expressed anteriorly in the embryo and relatively early on in development. The requirement for temporal collinearity during development would act to conserve the cluster, he said.

Meanwhile, despite fragmentation of its Hox cluster, Oikopleura appears to have retained spatial collinearity in the disparate genes - the genes are dispersed, and therefore not temporally collinear, but they are expressed in the right order along the body axis.

Michael Akam, a developmental geneticist at the University of Cambridge, who was not involved in the study, agreed that Oikopleura's apparent spatial collinearity is significant. "It is probably patterning itself in ways very different from the vertebrate embryo, using individual signals to turn on individual Hoxgenes rather than some sort of timing mechanism," he told us. 
In this respect, said Chourrout, Oikopleura would resemble C. elegans, which undergoes a mosaic mode of development where all genes are expressed early in development rather than in a temporal sequence. Another similarity is that both have very fast development times and a small number of cells, which might, said Patel, allow them to "employ mechanisms that don't require strict anterior and posterior timing."

According to Chourrout, the findings also lend support to the conjecture, first made by Darwin, that tunicates are simplified chordates, rather than being particularly close to the chordate ancestor. They have undergone, "retrograde evolution," he said. "It's evolution with no return. Once you have broken a cluster of genes, it's very unlikely that selection will rebuild it" C. elegans also has a simplified body plan compared to its ancestors, Patel said.

\section{References}

1. Nature, [http://www.nature.com]

2. Daniel Chourrout, [http://www.sars.no/group1.html]

3. Oikopleura dioica: A tunicate model for the study of chordates, [http://www.genoscope.cns.fr/ externe/English/Projets/Projet_HG/organisme_HG.html]

4. Nipam Patel, [http://www.patellab.org/]

5. Organizing axes in time and space: 25 years of colinear tinkering

6. Michael Akam, [http://www.zoo.cam.ac.uk/museum/michael.htm]

This PDF file was created after publication. 